\title{
Age estimation through skeletochronology and mark-recapture of free-living Liolaemus leopardinus (Squamata: Liolaemidae) from Chile
}

\author{
Enrique Santoyo-Brito, ${ }^{1}$ Stanley F. Fox, ${ }^{1}$ and Herman $\mathrm{Núñuz}^{2}$ \\ ${ }^{1}$ Department of Integrative Biology and Collection of Vertebrates, Oklahoma State University, Stillwater, Oklahoma, 74078, \\ USA. E-mails: enrique.s.brito@okstate.edu, stanley.fox@okstate.edu. \\ 2 Área Zoología, Museo Nacional de Historia Natural de Chile. E-mail: herman.nunez@mnhn.cl.
}

\begin{abstract}
Age estimation through skeletochronology and mark-recapture of free-living Liolaemus leopardinus (Squamata: Liolaemidae) from Chile. Age determination is a crucial component of ecological studies. Researchers have relied on different methods and techniques, for example mark-recapture, body size, and skeletochronology, to assess the age of free-ranging individuals. We used all three methods to estimate the age structure of a population of Liolaemus leopardinus, a highly social and saxicolous lizard species endemic to the temperate region of central Chile. This high-elevation and secretive species is considered threatened and, although efforts have been made to reveal more specific details about the species' natural history, crucial details of its biology are still unknown. Our goal was to associate the number of Lines of Arrested Growth (LAGs) to snout-vent length (SVL) and use LAGs as an age estimation proxy on free-ranging individuals. For the skeletochronology analyses, a combination of toe-clips was collected when each subject was first captured in 2012-2013. SVL for all captured individuals was recorded during two different field seasons (austral spring to fall of 2011-2012 and 2012-2013). SVL data were also available for 10 individuals initially collected and permanently marked in 2005 (one juvenile and nine adults) and recaptured in 2011-2012. Three of those 10 subjects were captured again in 2012-2013. Our results revealed the formation of LAGs in L. leopardinus and a high degree of bone remodeling in both juveniles and adults. This bone remodeling combined with the high rapprochement in peripheral LAGs on the samples of the oldest lizards suggest that phalangeal bones are not suitable for age determination in this species. On the other hand, our mark-recapture results allowed us to assign individuals to four different age-classes when a subject's SVL was associated with activity periods and recaptures. Individuals of $L$. leopardinus are long-lived and their lifespan can exceed a decade. Female lizards become sexually mature at three to four years of age.
\end{abstract}

Keywords: bone, body-length, high-altitude, lifespan, lines of arrested growth, lizards.

Received 19 December 2017

Accepted 15 May 2018

Distributed June 2018 


\begin{abstract}
Resumo
Estimativa etária por meio de esqueletocronologia e marcação-e-recaptura de Liolaemus leopardinus (Squamata: Liolaemidae) do Chile. A determinação etária é um componente crucial de estudos ecológicos. Pesquisadores tem usado diferentes técnicas e métodos como marcação-erecaptura, tamanho do corpo e esqueletocronologia, para avaliar a idade de indivíduos na natureza. Usamos esses três métodos para estimar a estrutura etária de uma população de Liolaemus leopardinus, uma espécie de lagarto saxícola, altamente social e endêmica da região temperada do centro do Chile. Essa espécie secretiva de grandes altitudes é considerada ameaçada, e apesar dos esforços para descobrir detalhes específicos sobre a sua história natural, detalhes cruciais de sua biologia permanecem desconhecidos. Nosso objetivo foi associar o número de Linhas de Crescimento (LAGs) ao comprimento rostro-cloacal (SVL) e usar as LAGs para representar uma estimativa etária dos indivíduos na natureza. Para as análises de esqueletocronologia, foi coletada uma combinação de cortes de artelhos quando cada indivíduo foi capturado pela primeira vez em 2012-2013. O SVL de todos os indivíduos capturados foi registrado durante duas campanhas consecutivas (primavera a outono de 2011-2012 e 2012-2013). Os dados de SVL estiveram também disponíveis para 10 indivíduos coletados anteriormente e marcados de forma permanante em 2005 (um juvenil e nove adultos) e recapturados em 2011-2012. Três daqueles 10 indivíduos foram capturados novamente em 2012-2013. Nossos resultados revelaram a formação de LAGs em L. leopardinus e um alto grau de remodelação óssea tanto nos junevis como nos adultos. Essa remodelação ósssea combinada com a alta aproximação das LAGs periféricas nas amostras dos lagartos mais velhos sugere que os ossos das falanges não são adequados para a determinação etária nessa espécie. Por outro lado, nossos resultados de marcação-e-recaptura permitiram classificar os indivíduos em quatro diferentes classes etárias quando o SVL de um indivíduo era associado com os períodos de atividade e recapturas. Indivíduos de L. leopardinus são longevos, podendo exceder uma década. As fêmeas tornam-se sexualmente maduras aos três ou quatro anos de idade.
\end{abstract}

Palavras-chave: comprimento do corpo, grandes altitudes, lagartos, linhas de crescimento, longevidade, osso.

\section{Introduction}

Accurate age determination is a very important aspect in studies of population ecology (Borczyk and Paśko 2011, Comas et al. 2016), but it is of particular relevance on those conducted on threatened species (Lindquist et al. 2012) or on those for which little is known about their demography (Comas et al. 2016). The most direct and reliable method to assess the age of free-ranging subjects is to gather life history and morphometric data through the lifespan of a cohort of newborns (Halliday and Verrell 1988, Castanet 1994). This is achieved by marking and recapturing the animals systematically, measuring them, and building growth curves or displaying the data in charts showing the lifetime relationship between age and growth (Halliday and Verrell 1988, Forester and Lykens 1991, Arakelyan et al. 2013). However, following individuals of a cohort over time can be a challenge if the species of interest is long-lived or elusive (Castanet 1994, Lemos-Espinal et al. 2005, Mills 2006). Therefore, researchers have relied on the size-frequency method and used body size as a proxy for age of free-ranging animals as both traits are positively correlated (Castanet 1994, Chen et al. 2011, Comas et al. 2016). To utilize the size-frequency method, a large number of animals are captured and measured during a short period of time, the data are displayed in a histogram, and age-classes are 
assigned based on the size-frequency distribution (Halliday and Verrell 1998). The size-frequency method requires a clear-cut knowledge of agespecific variation in body size of the species studied to avoid overlapping age-classes (Gibbons 1976, Halliday and Verrell 1988, Castanet 1994). But, in order to minimize overlaps, researchers tend to group subjects into only two, three, or sometimes four age-classes (Halliday and Verrell 1988, Castanet 1994, Borczyk and Paśko 2011).

In addition to the methods mentioned above, researchers have focused their efforts on the study of natural cyclic growth marks recorded in large bones-skeletochronology (Kleinenberg and Smirina 1969, Castilla and Castanet 1986, Castanet 1994, Guarino et al. 2010). In vertebrates, bone grows by an appositional process of surface deposition (Enlow 1963, Piantoni et al. 2006, Arakelyan et al. 2013, Çiçek et al. 2015). Bone growth occurs when the subject is active and resources are available for its development (Adolph and Porter 1993, Castanet 1994, Valdecantos et al. 2007, Comas et al. 2016). The appositional surface deposition can be observed as concentric rings through cross sections of long bone diaphysis, such as the femur or humerus (Comas et al. 2016). Bone growth appears as a broad zone followed by a fine, but well-defined dark line (Halliday and Verrell 1988, Valdecantos et al. 2007, Prieto et al. 2013). The line in the shape of a ring is known as a Line of Arrested Growth (LAG) and indicates a period of drastically constrained growth, e.g., brumation (Halliday and Verrell 1988, Vitt and Caldwell 2009, Guarino et al. 2015). LAGs are formed yearly in species that inhabit well defined seasons, for example, temperate regions (Ortega-Rubio et al. 1993, Piantoni et al. 2006). Skeletochronology has been considered for more than 30 years a rigorous and trustworthy technique to age freeranging reptiles (Castanet 1982, Comas et al. 2016); its results are more accurate than that of any other known criterion of age estimation (Castanet et al. 1988). Skeletochronology studies often involve large numbers of animals being sacrificed when long bones are used, which can be of concern when the species under study is threatened. As an alternative to long bones, researchers have used phalanges since those offer similar results when compared to results obtained from long bones, and most importantly, removing a toe is non-lethal (Ledentsov and Melkumyan 1986, Yakin et al. 2015, Comas et al. 2016). Skeletochronology has been applied successfully in studies of different animal groups, for example, mammals (Frylestam and Schantz 1977, Castanet et al. 2004), and amphibians and reptiles (Halliday and Verrell 1988, Castanet 1994, Guarino et al. 2015, Comas et al. 2016).

Liolaemus leopardinus Müller and Hellmich, 1932 is a medium-to-large, high-elevation, nonterritorial, viviparous lizard endemic to temperate central Chile (Pincheira-Donoso and Núñez 2005). The species is limited to a narrow altitudinal band (2100-2800 $\mathrm{m}$ a.s.l.), and assessed as Endangered by IUCN (Díaz et al. 2016). It is active approximately seven months during the austral spring to fall and inactive during the cool and snowy austral winter. Little is known about the species' population demography, but different studies have assigned subjects to two or three age-classes-neonates, juveniles, and adults-solely on their snout-vent length (SVL) (Carothers et al. 1997, Fox and Shipman 2003, E. Santoyo-Brito pers. comm.), or categorized individuals as mature based on the body size at sexual maturity: SVL $68.0 \mathrm{~mm}$ (Leyton and Valencia 1992). However, information on the age structure and lifespan of the species obtained through a more thorough or accurate method has never been gathered. Information on both traits is critical when so little is known about this endangered endemic species. Our main objective in this study was to determine whether skeletochronology is a useful method to estimate age in L. leopardinus. We also aimed to determine the relation between SVL and the number of LAGs so as to use SVL as a proxy to estimate the age of free-ranging $L$. leopardinus. 


\section{Materials and Methods}

We collected free-ranging Liolaemus leopardinus of different SVLs during their active season (austral spring to fall; December-April) in 20112012 and 2012-2013 and right after emerging from brumation in November and December, 2013, at El Colorado in the Andean cordillera of central Chile (Fox and Shipman 2003, E. Santoyo-Brito pers. comm.), $35 \mathrm{~km}$ northeast of Santiago at $2760 \mathrm{~m}$ a.s.1. (33 $\left.14^{\prime} \mathrm{S}, 70^{\circ} 16^{\prime} \mathrm{W}\right)$. All lizards were caught via noosing, their SVL measured with a ruler, and sex determined by the presence (males) or absence (females) of precloacal pores when a hemipenal bulge was not observed. Subjects were assigned to one of three age-classes, neonates (40.0 to $45.0 \mathrm{~mm}$ ), juveniles (57.0 to $67.0 \mathrm{~mm}$ ) (E. Santoyo-Brito pers. comm.), or adults (> $67.0 \mathrm{~mm})$ based on the body size when females reach sexual maturity (i.e., presence of follicles) (Leyton and Valencia 1992). We evaluated sexual size dimorphism between the five largest adults of both sexes using a Student's t-test. Statistical tests were completed using SPSS version 21.

All captured lizards were permanently marked by a unique toe clip combination and assigned a unique dorsal color combination of painted dots, which they lost at molting. This individual marking allowed recognition of freeranging individual lizards since subjects were part of a large behavioral ecology study. Marked subjects were recaptured only when the color code was missing or incomplete. Clipped toes from each individual caught in the course of the field season of 2012-2013 were collected for subsequent skeletochronology analyses. Excised digits were deposited into a dry Eppendorf centrifuge vial labeled with the unique toe clip combination of the individual. After we obtained the morphometric data and collected the clipped toes, all lizards were released at their site of capture.

The skeletochronology laboratory work was carried out in 2015 at Oklahoma State University.
First, we chose the longest of the toe clips collected in the field from each lizard. Toe clips had been stored dry in individual Eppendorf vials. Then we placed all samples in $95 \%$ ethanol for fixation for at least $24 \mathrm{~h}$, ensuring that the individual identity of each toe clip was maintained. Soft tissue was carefully removed manually from most of the toe clip and the bone of the second phalange detached. The length of the bone was measured to the nearest $0.25 \mathrm{~mm}$ using an optical micrometer to estimate the number of cuts needed to obtain slices from the mid-section of the bone. All bones were decalcified using Fisher Scientific Cal-Ex ${ }^{\circledR}$ II (Product \# MFCD00211744) for 8 h. Each phalange was removed from its cassette and embedded in a block of paraffin for its transversal sectioning with a manual microtome. Slice thickness was set to $10 \mu \mathrm{m}$, and a ribbon of serial cross sections of 10 to 12 slices was placed on a microscope slide and stained with Harris' hematoxylin. Slices were obtained from the middiaphysis of the phalange, which is considered to yield the best sections for accurate aging. For a detailed description of the skeletochronology method, refer to McCreary et al. 2008.

All stained slides were observed utilizing an upright research Olympus microscope BX51 (200 and 400x-magnification). We took a series of photographs of different slices from each bone utilizing a digital camera (Q Colour 5 Olympus) attached to the oculars of the microscope. Three to 10 of the best photographs of different sections of each sliced toe clip were selected to estimate the number of LAGs. Each photograph was enlarged using the morphometric software tpsDig (Rohlf 2004) to count the LAGs. Samples with observed double lines were discarded for age determination (Bülbül et al. 2016). It was not possible to estimate the loss of one or more innermost LAGs by means of osteometric analysis because we analyzed phalanges of different toe clips with different diaphyseal diameters, thus they were not comparable (Guarino et al. 2010, 2015). 


\section{Results}

\section{Objective 1}

Combining both field seasons (2011-2012 and 2012-2013), we captured and permanently marked a total of 179 free-ranging lizards of different ages (neonates, juveniles, and adults). The range of SVL for all subjects was 40.0 to $102.0 \mathrm{~mm}$. There was no sexual size dimorphism in SVL (t-test: $\left.t_{(8)}=1.518 ; p=0.168\right)$ between the five largest males (range $=99.0$ to $102.0 \mathrm{~mm}$, mean $=100.8 ; \mathrm{SD}=1.15)$, and females $($ range $=$ 99.0 to $102.0 \mathrm{~mm}$, mean $=99.6$; $\mathrm{SD}=1.34$ ). Although there is no statistically significant size dimorphism in the species, males are slightly bigger than females.

For the skeletochronology analyses, we had to exclude samples of 30 lizards because the bone became detached from the paraffin block during the slicing process in a few cases (on several occasions it was not possible to re-embed the bone and place it in its correct vertical position due to its very short length), or more often due to the inferior quality of the slide (i.e., poor staining or poor tissue slice). The exclusion of those samples reduced our sample size to 43 . In all stained cross sections, we observed a medullar cavity, endosteal deposition and periosteal bone, and growth zones delimited by thin hematoxylinophilic outer lines corresponding to LAGs. Rapprochement of peripheral LAGs was observed mostly in adults (Figure 1).

An unexpected result in our study was that almost all samples of juveniles, not just adults, showed some degree of bone remodeling (Figure 1). We identified scalloped lines indicative of bone remodeling, and in most cases the remodeling was so extensive that counting LAGs was not feasible, facing the risk of false counts and underestimating age of the lizards. The degree of remodeling and endosteal deposition was such that we could not estimate the number of lost LAGs, not even via image overlap.
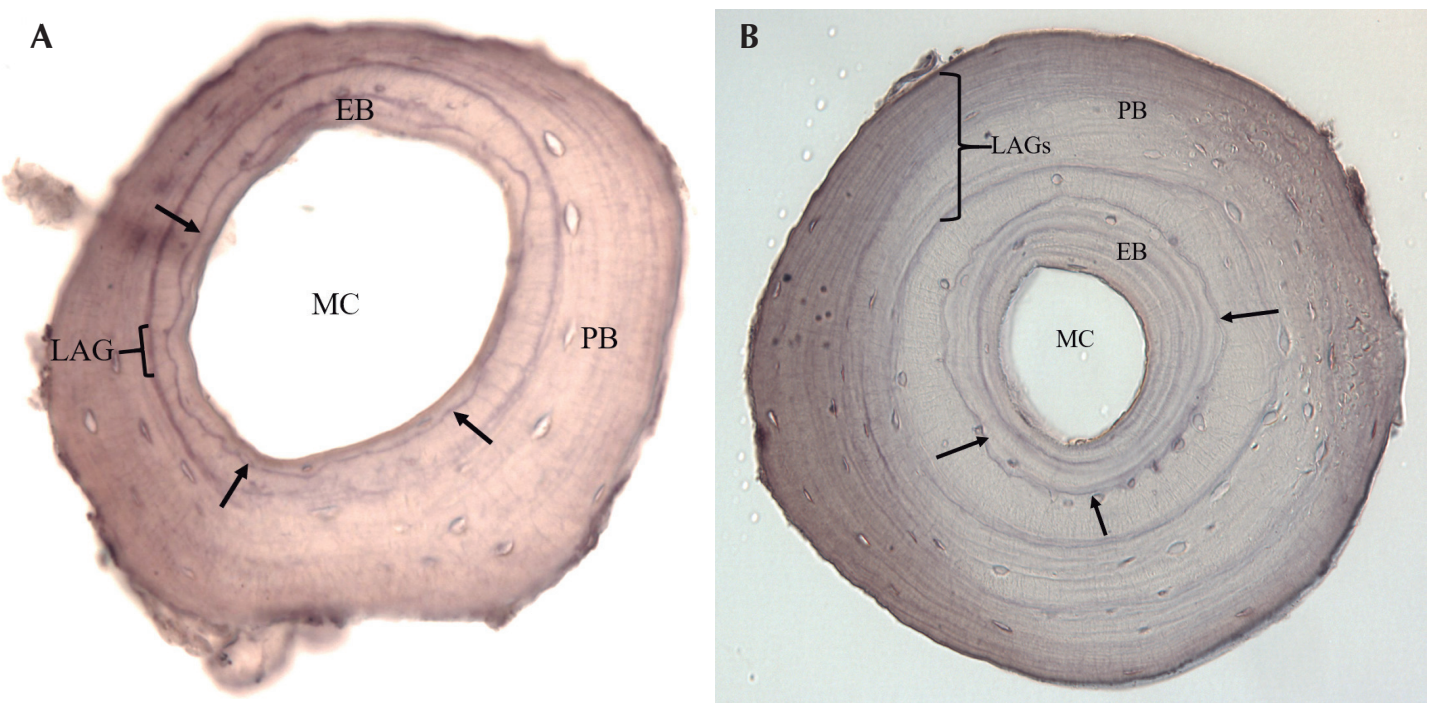

Figure 1. Cross section (400×-magnification) through the mid-section diaphysis of a phalange of (A) GOGO (juvenile female, SVL $=65.0 \mathrm{~mm}$ ) and $(\mathbf{B})$ BBGB (adult male, SVL $=92.0 \mathrm{~mm}$ ) Liolaemus leopardinus lizard caught on 12 and 13 February 2013, respectively, at El Colorado in the Andean cordillera of central Chile. Black arrows point to the limit of the remodeling zone, and brackets indicate Lines of Arrested Growth (LAGs) formed during each brumation period. $\mathrm{MC}=$ marrow cavity; $\mathrm{EB}=$ endosteal bone; $\mathrm{PB}=$ periosteal bone. 
Presence of this high degree of bone remodeling was confirmed by researchers more experienced with this technique (Ballard and Sinsch, pers. comm.). Furthermore, because of extensive rapprochement, we could not confidently count peripheral LAGs, either.

\section{Objective 2}

We also aimed to assess the degree of association between SVL and the number of LAGs to use length as an age proxy on freeranging lizards. However, we could not estimate the correlation between both variables due to the problems faced in the skeletochronology analyses. Consequently, we plotted the SVL of all subjects caught in either or both field seasons, which allowed us to assign subjects into one of four different age-classes-neonates, yearlings, juveniles, and adults-by associating SVL and active and inactive (brumation) periods of the year (Figure 2). We know that lizards are active from October to mid-April and that subjects of the population brumate from mid-April to October. Mothers give birth during March and April (neonates' mean SVL $=40.6 \mathrm{~mm}$ ); thus, the smallest subjects found in the field in November right after brumation are the now 7-8 month-old neonates (mean SVL $=48.8 \mathrm{~mm}$ ). The complete lack of data points between 49 and $56 \mathrm{~mm}$ in Figure 2 suggests that the yearling cohort is missing in both active periods (AP) depicted in the figure. Those lizards that start the active period at a size of 56-62 $\mathrm{mm}$ appear to be second-year juveniles, and all subjects whose SVL is 68.0 or above should be considered adults. Following Leyton and Valencia (1992), we assumed that the species reaches sexual maturity during the third to fourth year of age; when lizards' SVL is $\sim 68.0 \mathrm{~mm}$.

Interestingly, during our two field seasons of 2011-2012 and 2012-2013 we captured 10 subjects that were first caught and permanently marked during a pilot study at the same site from December 2004 to April 2005 (Table 1). Unfortunately, it was not possible to age these animals using skeletochronology due to the remodeling and rapprochement problems discussed above.

Nine of the subjects caught in 2004-2005 fit into the adult age-class and one was assigned to the juvenile age-class based on Figure 2. The average SVL for the six adult males in 20042005 was $94.0 \mathrm{~mm}$ and for the three females was $81.6 \mathrm{~mm}$. By associating the SVL at different periods of activity depicted in Figure 2, we suggest that these adult lizards were at least 4 to 5 years old when first captured. Seven years later at recapture those subjects should have been at least 11 to 12 years old or more since their SVL was close to the upper bound of the SVL range $(102.0 \mathrm{~mm})$ for all subjects caught in either of our two field seasons (Figure 2).

\section{Discussion}

We provide results on the first attempt to estimate age in Liolaemus leopardinus lizards through skeletochronology. Our main goal was to determine the effectiveness of the aging method using phalanges of individuals. Unfortunately, the objective was not fulfilled since we faced problems during the skeletochronology. First, although the staining method (stained with Harris' hematoxylin) was the same for all samples, the optical sharpness varied among tissue slices, making it sometimes difficult to unmistakably identify the LAGs. Misinterpretation of LAGs is common when they are not strongly expressed (i.e., clearly defined and stained) (Castanet and Smirina 1990) and double lines, probably formed due to temporary, shortterm ecological factors (i.e., very high temperatures, very dry conditions, variations in food availability, etc.) in the environment (Jakob et al. 2002), could be interpreted as two LAGs. Second, unexpectedly we observed a high degree of bone remodeling (i.e., scalloped surfaces and deposition of endosteal bone) in most samples. Replacement of most of the periosteal bone by endosteal bone left very little suitable bone tissue for age estimation. Owing to this, it was not 
Age estimation through skeletochronology and mark-recapture of free-living Liolaemus leopardinus

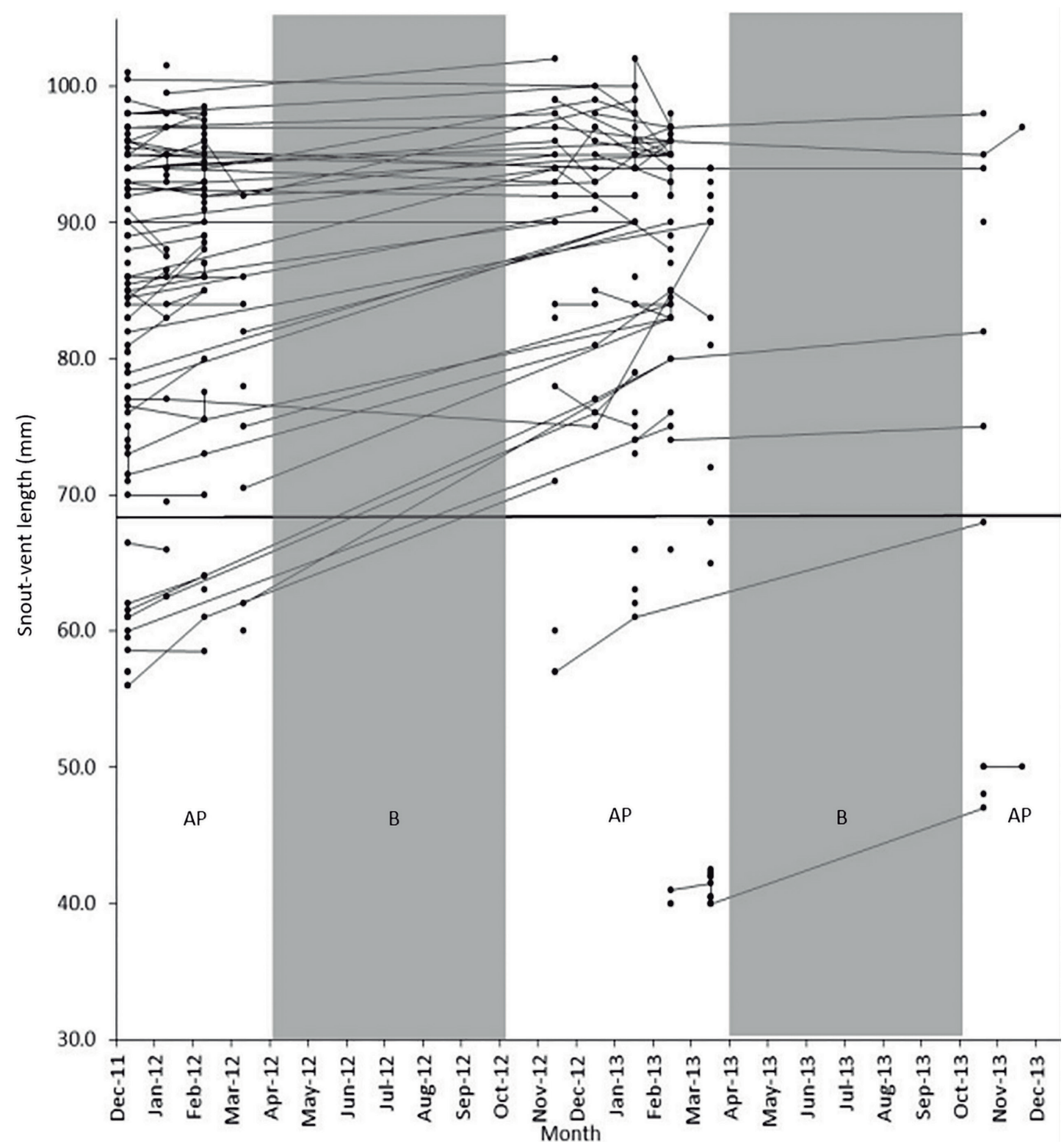

Figure 2. Snout-vent length of 179 Liolaemus leopardinus lizards caught during the late austral spring to fall of $2011-$ 2012 and 2012-2013 and November-December of 2013, at El Colorado, Chile. Solid circles represent each of the lizards caught and lines link their subsequent recaptures. Bold horizontal line at $68 \mathrm{~mm}$ represents minimal size at sexual maturity. $\mathrm{AP}=$ active period; $\mathrm{B}=$ brumation. 
Table 1. Snout-vent length (SVL, in $\mathrm{mm}$ ) of 10 Liolaemus leopardinus lizards first caught during the austral summer and fall (December-April) in 2004-2005 and recaptured during the same seasons in 2011-2013 at El Colorado in the Andean cordillera of central Chile. Age-classes: $A=$ adults, $\mathrm{J}=$ juveniles.

\begin{tabular}{|c|c|c|c|c|c|c|c|}
\hline \multirow[b]{3}{*}{ Toe-clip } & \multirow[b]{3}{*}{ Sex } & \multicolumn{6}{|c|}{ Field season } \\
\hline & & \multicolumn{2}{|c|}{ 2004-2005 } & \multicolumn{2}{|c|}{$2011-2012$} & \multicolumn{2}{|c|}{ 2012-2013 } \\
\hline & & Age-class & SVL & Age-class & SVL & Age-class & SVL \\
\hline $1-7-11-18$ & $\pi$ & A & 91.5 & A & 98.0 & - & - \\
\hline $1-8-11-17$ & $0^{\pi}$ & A & 94.5 & A & 98.0 & - & - \\
\hline $1-8-11-20$ & 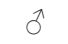 & $A$ & 94.0 & A & 100.5 & A & 100.0 \\
\hline $1-6-12-13-16-17-19$ & $\hat{\sigma}$ & A & 94.0 & A & 98.0 & - & - \\
\hline $1-6-11-19$ & $\pi$ & A & 94.5 & A & 99.5 & A & 102.0 \\
\hline $1-9-11-16$ & $\lambda^{\lambda}$ & A & 96.0 & A & 101.0 & - & - \\
\hline $1-9-20$ & q & A & 82.0 & A & 94.0 & - & - \\
\hline $1-7-11-20$ & 우 & J & 63.0 & A & 98.0 & A & 100.0 \\
\hline $1-9-12-16$ & q & A & 94.0 & A & 98.0 & - & - \\
\hline $1-9-14$ & q & $A$ & 69.0 & A & 99.0 & - & - \\
\hline
\end{tabular}

possible to obtain reliable age estimates for most of the specimens in our study through skeletochronology (Sinsch pers. comm.). It has been shown that bone remodeling increases as individuals get older (Castilla and Castanet 1986) and considerable remodeling and rapprochement of peripheral LAGs has been detected in long-lived species (Wagner et al. 2011, Ergül et al. 2014). Remodeling is the result of bone growth (Enlow 1963) by eroding and reshaping the periosteal bone on the edge of the marrow cavity; this phenomenon can cause the complete loss of one or more LAGs (Ergül et al. 2014). Remodeling could be the result of environmental conditions (Smirina 1972) in a habitat with harsh weather and possibly limited resources as is recognized in high altitude or high latitude regions (Nagy and Grabherr 2009, Ergül et al. 2014). During bone growth, rebuilding also occurs by endosteal deposition (Enlow 1963, Curtin et al. 2005), which was notably present in our samples. Third, we observed rapprochement of peripheral LAGs, which reduces the reliability of age estimates (Wagner et al. 2011, Sinsch 2015). Obviously, reliability of skeletochronology depends on the correct identification and interpretation of LAGs (Castanet and Smirina 1990, Guarino et al. 1999), and our samples did not yield sufficient reliability. Thus, a true estimation of age using LAGs was not possible in our study.

Sexual size dimorphism was not evident in $L$. leopardinus, but the largest males were slightly larger than the largest females. Thus, we suggest that adult males may live longer than adult females, since reptiles generally show indeterminate growth. If so, the longer lifespan in males might have a genetic basis (Badyaev 2002, Cox et al. 2009, Barret and Richardson 2011) since males do not defend territories or females, and do not engage in agonistic behavior against male conspecifics (Fox and Shipman 2003, ESB pers. observ.), while females face the energetic challenge of viviparous reproduction.

Although toe-clipping is considered an invasive marking technique, there actually is 
little negative impact of toe clipping on reptiles (Perry et al. 2011). A recent study conducted on 10 different lizard species concluded that removing a low number of toes (two to three; our maximum number of toe-clips was three and only one per foot) have the lowest negative impacts (Olivera-Tlahuel et al. 2017). We did not observe any change in behavior of individuals before and after toe clipping, and this marking method did not seem to decrease the chance of recapturing individuals (ESB and SF pers. observ). Body-size measurements derived from the mark-recapture data collected during three field seasons aided us in assigning individuals to four different age-classes. We assigned young specimens to one of three age-classes: neonates, yearlings, or juveniles based on active periods. Interestingly, Figure 2 suggests that the yearling cohort is missing from our dataset; the lack of these data could be the result of our search effort, however. During both field seasons we mainly searched for lizards located on the rock outcrops since we were not then aware of the secretive behavior of neonates and yearlings (E. SantoyoBrito pers. comm.). However, it is probable that most of the 7-8 month "new yearlings" cohort is missing because of heavy bird predation on neonates documented at our field site (E. Santoyo-Brito pers. comm.), and so the density of the "new yearlings" might be very low, making it difficult to observe them in the field. It is probable that adults live so long-resulting in higher density of the multi-year adult age class compared to juvenile age-classes - and continue to reproduce throughout their long lives as evolutionary compensation for heavy mortality of neonates and small juveniles.

Nevertheless, for three main reasons our results should be taken with caution and be considered as a mere age-class designation and not an absolute age estimator (Halliday and Verrell 1988, Castanet 1994). First, in our study we did not follow a cohort of known-age individuals (i.e., neonates) through their lifespan; our mark and recapture data were limited roughly to three active seasons. Second, we did not continuously recapture known subjects and their recapture was limited to the event of missing color codes, which limited the accumulation of data on SVL. Third, L. leopardinus as an ectotherm strongly depends on ecological and physiological conditions (i.e., thermal environments, length of activity period, food availability, etc.) to grow, but most importantly those conditions could differ within a season (Adolph and Porter 1993, Peacor 2002, Roitberg and Smirina 2006), thus increasing body size variability within age-classes (Halliday and Verrell 1988, Castanet 1994).

The SVL of 10 individuals first captured in 2005 and recaptured in 2011-2012 (three captured again in 2012-2013) shows that $L$. leopardinus is a long-lived species. Although a lifespan of up to 12 years or more could sound overstated for a medium-sized lizard, other lizard species located at high elevations are also known to be long-lived. For example, a skeletochronology study suggested that one adult female from a 60-70 mm cohort of the viviparous L. multicolor Koslowsky, 1898 was 19 years of age (Valdecantos et al. 2007), and Phymaturus patagonicus Koslowsky, 1898 (SVL = 88.0-109.0 mm) can live up to 16 years (Piantoni et al. 2006). However, for L. multicolor the authors suggest caution since that specific finding might be an outlier and not accurately represent what occurs within the remaining sample. Even so, they report a mean life span of 12 years for $L$. multicolor (Valdecantos et al. 2007). Longevity in L. leopardinus could be explained in part due to the selective predation pressure on smaller body sizes (Reznick 1996, Costelloe and Rubenstein 2015, E. Santoyo-Brito pers. comm.). Although several predatory species are located at El Colorado (Fox and Shipman 2003, SantoyoBrito et al. 2014), predation decreases once subjects reach the size of older juveniles and beyond (E. Santoyo-Brito pers. comm.). The survival benefit derived from having achieved a large body size has been shown in other lizard species. For example, larger (and older) Egernia stokesii (Gray, 1845) were more prone to 
recapture nine years later than smaller lizards (Pearson et al. 2016). In addition to body size, the short length of the activity season at highelevation sites decreases predation opportunities (Wapstra et al. 2001, Roitberg and Smirina 2006), resulting in increased longevity (Piantoni et al. 2006, Cabezas-Cartes et al. 2015).

In summary, our skeletochronology results using phalanges did reveal the formation of LAGs in subjects of L. leopardinus. However, the high degree of remodeling and rapprochement make the method poorly suited for aging individuals. However, before utterly discarding the method, it is necessary to examine a long bone like the femur, which has been shown to be very suitable for skeletochronology (Castanet et al. 1998, Piantoni et al. 2006, Guarino 2010). We also suggest collecting a larger number of samples corresponding to free-ranging neonates and yearlings to back-calculate the number of LAGs lost if remodeling is present also in the femur. However, collecting free-ranging neonates is not an easy task since they are rarely found in the field due to their secretive and cryptic behavior (E. Santoyo-Brito pers. comm.). Most importantly, and a serious detraction, is that to obtain a femur it is necessary to euthanize individuals, an undesirable option when studying L. leopardinus, which is endangered. The SVL and recapture of different individuals increased our accuracy to assign subjects to one of four distinctive age-classes. The recapture of one juvenile and nine adults first captured in 2004 2005 and recaptured in 2011-2012 indicates without a doubt that L. leopardinus individuals may live more than a decade.

\section{Acknowledgments}

We thank J. Grindstaff, M. Lovern, and T. O'Connell for critically reading the manuscript and offering constructive input throughout the study. M. Bolek and C. Anaya for advice and access to laboratory equipment. This research was made possible due to funding by The National Geographic Society, Delta Foundation, the Southwestern Association of
Naturalists, and Oklahoma State University. Research was conducted according to ACUP AS-11-13 approved by Oklahoma State University IACUC. We thank field assistants D. Esquerré, M. Palma, N. Torres-Achiles, and J. Masseloux.

\section{References}

Adolph, S. C. and W. P. Porter. 1993. Temperature, activity, and lizard life history. American Naturalist 142: 273-295.

Arakelyan, M., R. Petrosyan, Ç. Ilgaz, Y. Kumlutaş, S. H. Durmuş, Y. Tayhan, and F. Danielyan. 2013. A skeletochronological study of parthenogenetic lizards of genus Darevskia from Turkey. Acta Herpetologica 8: 99-104.

Badyaev, A. V. 2002. Growing apart: an ontogenetic perspective on the evolution of sexual size dimorphism. Trends in Ecology and Evolution 17: 369-378.

Barrett, E. L. and D. S. Richardson. 2011. Sex differences in telomeres and lifespan. Aging Cell 10: 913-921.

Borczyk, B. and L. Paśko. 2011. How precise are size-based age estimations in the Sand Lizard (Lacerta agilis)? Zoologica Poloniae 56: 11-17.

Bülbül, U., M. Kurnaz, A. İ. Eroğlu, H. Koç, and B. Kutrup. 2016. Age and growth of red-belied lizard, Darevskia parvula. Animal Biology 66: 81-95.

Cabezas-Cartes, F., J. M. Boretto, and N. R. Ibargüengoytía. 2015. Age, growth and life-history parameters of an endemic vulnerable lizard from Patagonia, Argentina. Herpetological Journal 25: 215-224.

Carothers, J. H., S. F. Fox, P. A. Marquet, and F. M. Jaksic. 1997. Thermal characteristics of ten Andean lizards of the genus Liolaemus in central Chile. Revista Chilena de Historia Natural 70: 297-309.

Castanet, J. 1982. Recherches sur la croissance du tissu osseux des reptiles. Application: la méthode squelettochronologique. Unpublished Ph.D. Dissertation. Université Paris VII, France.

Castanet, J. 1994. Age estimation and longevity in reptiles. Gerontology 40: 174-192.

Castanet, J. and E. M. Smirina. 1990. Introduction to the skeletochronological method in amphibians and reptiles. Annales des Sciences Naturalles, Zoologie Serie 11: 191-196.

Castanet, J., D. G. Newman, and H. S. Girons. 1988 Skeletochronological data on the growth, age, and 
population structure of the Tuatara, Shpenodon punctatus, on Stephens and Lady Alice islands, New Zealand. Herpetologica 44: 25-37.

Castanet, J., S. Croci, F. Aujard, M. Perret, J. Cubo, and E. de Margerie. 2004. Lines of arrested growth in bone and age estimation in a small primate: Microcebus murinus. Journal of Zoology, London 263: 31-39.

Castilla, M. A. and J. Castanet. 1986. Growth, age and longevity of Lacerta lepida assessed by skeletochronology. Pp. 331-336 in C. Miaud and R. Guyetant (ed.), Current Studies in Herpetology. Prague. Societas Europea Herpetologica.

Chen, W., T. L. Yu, and X. Lu. 2011. Age and body size of Rana kukunoris, a high-elevation frog native to the Tibetan plateau. Herpetological Journal 21: 149-151.

Çiçek, K., M. Afsar, M. Kumaş, D. Ayaz, and C. V. Tok. 2015. Age, growth and longevity of Kotschy's Gecko, Mediodactylus kotschyi (Steindachner, 1870) (Reptilia, Gekkonidae) from Central Anatolia, Turkey. Acta Zoologica Bulgarica 67: 399-404.

Comas, M. M., S. Reguera, F. J. Zamora-Camacho, H. Salvadó, and G. Moreno-Rueda. 2016. Comparison of the effectiveness of phalanges vs. humeri and femurs to estimate lizard age with skeletochronology. Animal Biodiversity and Conservation 39: 237-240.

Costelloe, B. R. and D. I. Rubenstein. 2015. Coping with transition: offspring risk and maternal behavioural changes at the end of hiding phase. Animal Behavior 109: 217-225.

Cox, R. M., D. S. Stenquist, and R. Calsbeek. 2009. Testosterone, growth and the evolution of sexual size dimorphism. Journal of Evolutionary Biology 22: 15861598.

Curtin, A. J., P. F. N. Mouton, and A. Chinsamy. 2005. Bone growth patterns in two cordylid lizards, Cordylus cataphractus and Pseudocordylus capensis. African Zoology 40: 1-7.

Díaz, S., P. Espejo, G. Lobos, J. Mella, H. Núñez, and M. Ruiz de Gamboa. 2016. Liolaemus leopardinus. The IUCN Red List of Threatened Species 2016: e. T12004A69940961. Eletronic Database accessible at http://dx.doi.org/10.2305/IUCN.UK.2016-1.RLTS. T12004A69940961.en. Captured on 30 March 2017.

Enlow, D. H. 1963. Principles of Bone Remodeling, an Account of Post-Natal Growth and Remodeling Processes in Long Bones and Mandible. Springfield. Charles C. Thomas Publisher. 131 pp.

Ergül, T., N, Özdemir, Ç Gül, and M. Tosunoğlu. 2014. Variation in body size and age structure of Stellagama stellio (L., 1758) (Reptilia: Agamidae) from Turkey. Acta Zoologica Bulgarica 66: 65-72.

Fox, S. F. and P. A. Shipman. 2003. Social behavior at high and low elevations: environmental release and phylogenetic effects in Liolaemus. Pp. 310-355 in S. F Fox, J. K. McCoy, and T. A. Baird (eds.), Lizard Social Behavior. Baltimore. Johns Hopkins University Press.

Forester, D. C. and D. V. Lykens. 1991. Age structure in a population of Red-spotted newts from Allegheny Plateau of Maryland. Journal of Herpetology 25: 373-376.

Frylestam, B. and T. von Schantz. 1977. Age determination of European hares based on periosteal growth lines. Mammal Review 7: 151-154.

Gibbons, J. W. 1976. Aging phenomena in reptiles. Pp. 454475 in M. F. Elias, B. E. Eleftheriou, and P. K. Elias (eds.), Special Review of Experimental Aging Research. Maine. Experimental Aging Research, Inc.

Guarino, F. M. 2010. Structure of the femora and autotomous (postpygal) caudal vertebrae in the three-toed skink Chalcides chalcides (Reptilia: Squamata: Scincidae) and its applicability for age and growth rate determination. Zoologischer Anzeiger 248: 273-283.

Guarino F. M., M. Cammarota, and F. Angelini. 1999. Skeletochronology on femurs and phalanxes from some species of Italian amphibians. Rivista di Idrobiologia 38: $1-10$.

Guarino, F. M., I. Di Già, and R. Sidaco. 2010. Age and growth of the sand lizards (Lacerta agilis) from a high Alpine population of north-western Italy. Acta Herpetologica, Firenze 5: 23-29.

Guarino, F. M., F. Crovetto, M. Mezzasalma, and S. Salvidio. 2015. Population size, age structure and life expectancy in a Lacerta agilis (Squamata; Lacertidae) population from northwest Italian Alps. North-Western Journal of Zoology 11: 241-246.

Halliday, T. R. and P. A. Verrell. 1988. Body size and age in amphibians and reptiles. Journal of Herpetology 22: $253-265$.

Jakob, C., A. Seitz, A. J. Crivelli, and C. Miaud. 2002. Growth cycle of the marbled newt (Triturus marmoratus) in the Mediterranean region assessed by skeletochronology. Amphibia-Reptilia 23: 407-418.

Kleinenberg, S. E. and E. M. Smirina. 1969. A contribution to the method of age determination in amphibians. Zoologicheskii Zhurnal 48: 1090-1094.

Ledentsov, A. V. and L. S. Melkumyan. 1986. On longevity and growth rate in amphibians and reptiles in Armenia. Proceedings of the Zoological Institute of the Academy of Sciences of the USSR 158: 105-110. 
Lemos-Espinal, J. A., R. I. R. González, and J. J. Z. Vega. 2005. Técnicas Para el Estudio de Poblaciones de Fauna Silvestre. Tlalnepantla. Facultad de Estudios Superiores Iztacala, UNAM, CONBIO. 157 pp.

Leyton, V. and J. Valencia.1992. Follicular population dynamics: its relation to clutch and litter size in Chilean Liolaemus lizards. Pp. 123-134 in W. C. Hamlett (ed.), Reproductive Biology of South American Vertebrates. New York. Springer-Verlag, Inc.

Lindquist, E., M. Redmer, and E. Brantnert. 2012. Annular bone growth in phalanges of five Neotropical Harlequin Frogs (Anura: Bufonidae: Atelopus). Phyllomedusa 11: $117-124$.

McCreary, B., C. A. Pearl, and M. J. Adams. 2008. A Protocol for Aging Anurans Using Skeletochronology. Virginia. U.S. Geological Survey open-file report. 38 pp.

Mills, L. S. 2006. Conservation of Wildlife Populations: Demography, Genetics and Management. Oxford. Wiley-Blackwell. 326 pp.

Nagy, L. and H. Grabherr. 2009. The Biology of Alpine Habitats. Oxford. Oxford University Press. 376 pp.

Olivera-Tlahuel, C., H. A. Pérez-Mendoza, J. J. ZúñigaVega, L. C. Rubio-Rocha, B. C. Bock, R. I. RojasGonzález, J. G. Zamora-Abrego, E. Alzate, A. M. Ortega-León, R. J. Maceda-Cruz, F. R. Méndez-de la Cruz, H. H. Siliceo-Cantero, and R. Serna-Lagunes. 2017. Effect of toe-clipping on the survival of several lizard species. Herpetological Journal 27: 266-275.

Ortega-Rubio, A., M. Khodaddost, and R. Servín. 1993. Skeletochronology in Mezquite lizards, Sceloporus grammicus. Proceedings of the Oklahoma Academy of Sciences 73: 31-34.

Peacor, S. D. 2002. Positive effect of predators on prey growth rate through induced modifications of prey behaviour. Ecology Letters 5: 77-85.

Pearson, S. K., S. S. Godfrey, C. M. Bull, and M. G. Gardner. 2016. Larger lizards live longer in the group-living Egernia stokesii. Australian Journal of Zoology 64: $182-191$.

Perry, G., M. C. Wallace, D. Perry, H. Curzer, and P. Muhlberger. 2011. Toe clipping of amphibians and reptiles: science, ethics and law. Journal of Herpetology 45: $547-555$

Piantoni, C., N. R. Ibargüengoytía, and V. E. Cussac. 2006. Age and growth of the Patagonian lizard Phymaturus patagonicus. Amphibia-Reptilia 27: 385-392.

Pincheira-Donoso, D. and H. Núñez. 2005. Las especies chilenas del género Liolaemus Wiegmann, 1834 (Iguania: Tropiduridae: Liolaeminae) taxonomía, sistemática y evolución. Publicación Ocasional del Museo Nacional de Historia Natural, Chile 59: 7-486.
Prieto, A., A. Martínez-Silvestre, J. Soler, D. Bretones, E. Pascual, and J. Marí. 2013. Aportaciones al estudio osteocronológico en un ejemplar de Testudo hermanni. Boletín de la Asociación Herpetológica Española 24: $50-55$.

Reznick, D. 1996. Life history evolution in guppies: a model system for the empirical study of adaptation. Netherlands Journal of Zoology 46: 172-190.

Rohlf, F. J. 2004. tpsDig. Version 1.40. URL: http://life.bio. sunysb.edu/ee/rohlf/software.html.

Roitberg, E. S. and E. M. Smirina. 2006. Adult body length and sexual size dimorphism in Lacerta agilis boemica (Reptilia, Lacertidae): between-year and interlocality variation. Pp. 175-187 in C. Corti, P. Lo Cascio, and M. Biaggini (eds.), Mainland and Insular Lacertid Lizards: a Mediterranean Perspective. Florence. Firenze University Press.

Santoyo-Brito E., S. Fox, and H. Núñez. 2014 Predation by the Rufous-banded Miner, Geositta rufipennis, on the lizard Liolaemus leopardinus. Boletin del Museo Nacional de Historia Natural, Chile 63: 69-72.

Sinsch, U. 2015. Skeletochronological assessment of demographic life-history traits in amphibians. Herpetological Journal 25: 5-13.

Smirina, E. M. 1972. Annual layers in bones of Rana temporaria. Zoolicheskii Zhurnal 51: 1529-1534.

Valdecantos, S., F. Lobo, and V. Martínez. 2007. Estimación de edades, tamaño corporal y adquisición de la madurez sexual en dos especies de Liolaemus (Iguania: Liolaemidae). Cuadernos de Herpetologia 21: $27-40$

Vitt, L. J. and J. P. Caldwell. 2009. Herpetology: An Introductory Biology of Amphibians and Reptiles. $3^{\text {rd }}$ Edition. Burlington. Academic Press. 720 pp

Wagner, A., R. Schabetsberger, M. Sztatecsny, and R. Kaiser. 2011. Skeletochronology of phalanges underestimates the true age of long-lived Alpine newts (Ichthyosaura alpestris). Herpetological Journal 21: 145-148.

Wapstra, E., R. Swain, and J. M. O'Reilly. 2001. Geographic variation in age and size at maturity in a small Australian viviparous skink. Copeia 2001: 646-655.

Yakin, B. Y., K. Çiçek, M. Koyun, M. Gürken, S. Hayretdağ, and C. V. Tok. 2015. A skeletochronological analysis of a population of the Anatolia Newt, Neurergus strauchii (Steindachner, 1887) (Caudata: Salamandridae), in Eastern Anatolia, Turkey. Zoology in the Middle East 61: $332-338$

Editor: Jaime Bertoluci 